DOI: $10.33766 / 2524-0323.90 .239-247$

УДК 343.98

В. М. Плетенець,

кандидат юридичних наук, доцент, доцент кафедри криміналістики, судової медицини та психіатрії Дніпропетровського державного університету внутрішніх справ (м. Дніпро, Україна) e-mail: viktor_plet@i.ua iDhttps://orcid.org/0000-0002-3619-8624

\title{
МОЖЛИВОСТІ ВИКОРИСТАННЯ ФАКТОРУ РАПТОВОСТІ В УМОВАХ ПРОТИДІЇ РОЗСЛІДУВАННЮ
}

У статті роглядаються можливості використання фактору раптовості в подоланні проявів протидії розслідуванню. Наголошується, що конфлікт інтересів обумовлює формування протистояння між указаними сторонами, котрий ускладює процес розслідування. Встановлення ж обставин події стає можливим шляхом неочікуваного для відповідних учасників застосування заходів з боку правоохоронців. Відстоюється позиція, що спостереження та оцінка впливу на протиборчу розслідуванню особу є критеріями правильності застосування фактору раптовості. Метою його використання виступають достовірні відомості про обставини розслідуваної події. Наголошується на необхідності врахування не тільки моменту, а й характеристик суб์'єкту застосування розглядуваного фактору.

Ключові слова: фактор раптовості, слідчі (розшукові) дії, інформація про обставини події, прояви протидії розслідуванню.

Постановка проблеми. Під час розслідування стикаються дві сторони, кожна з яких переслідує власні інтереси. Так сторона обвинувачення намагається зібрати достатню кількість відомостей для притягнення винуватця до відповідальності, а сторона захисту - уникнути або звести до мінімуму покарання. Конфлікт інтересів призводить до формування протистояння між вказаними сторонами, що впливає на організаційно-тактичну діяльність слідчого. Існуюча з боку зацікавлених осіб протидія ускладнює процес розслідування, а їі подолання значною мірою обумовлена неочікуваним характером дій правоохоронців.

Аналіз останніх досліджень і публікацій. Питанням застосування фактору раптовості цікавилися у своїх роботах такі вчені, як: Т. В. Авер'янова, Ю. П. Аленін, К. В. Антонов, О. М. Бандурка, В. П. Бахін, Р. С. Белкін, В. Д. Берназ, В. В. Бірюков, О. М. Васильєв, А. Ф. Волобуєв, В. І. Галаган, В. Г. Гончаренко, В. А. Журавель, А. В. Чщенко, Н. С. Карпов, В. С. Кузьмічов, Н. І. Клименко, О. Н. Колесниченко, В. О. Коновалова, В. П. Колмаков, В. В. Лисенко, В. К. Лисиченко, В. Г. Лукашевич, С. Д. Лук'янчиков, Г. А. Матусовський, В. Т. Нор, О. В. Одерій, М. В. Салтевський, М. Я. Сегай, О. П. Снігерьов В. В. Тищенко, Л. Д. Удалова, П. В. Цимбал, К. О. Чаплинський, Ю. М. Чорноус, В. Ю. Шепітько, М. Є. Шумило, М. П. Яблоков та ін.

(C) Плетенець В. М., 2020 
Безпосередньо дослідженню проблем протидії розслідуванню приділяли увагу такі вчені-криміналісти: О. В. Александренко, І. В. Грищюк, В. М. Карагодін, І. А. Ніколайчук, В. В. Трухачов, Е. У. Бабаєва, С. Ю. Журавлев, Л. В. Лившищ, В. Я. Куликов, А. Н. Петрова, Р. М. Шехавцов, Б. В. Щур та інші.

Водночас правоохоронці відчувають труднощі в застосуванні фактору раптовості в розслідуванні, особливо за умов протидії зазначеній діяльності з боку зацікавлених осіб. Наслідком цього стають складність отримання всієї сукупності відомостей за кримінальним правопорушенням. Таким чином, вирішення проблематики подолання проявів протидії з використанням фактора раптовості обумовлюють потребу приділення цьому окремої уваги.

Формулювання цілей. Метою даної статті є окреслення можливостей використання правоохоронщями фактору раптовості в умовах протидії розслідуванню.

Виклад основного матеріалу. У фаховій літературі раптовість розглядається як елемент характеристики дій слідчого й особи, котра йому протистоїть; як характеристика події, що підлягає розслідуванню. Через те рекомендується використання чинника раптовості при проведенні слідчих дій, прийнятті та реалізації процесуальних рішень у кримінальній справі [1;2].

У більшості робіт, присвячених організації та тактиці проведення слідчих (розшукових) дій, визначається прямо-пропорційний зв'язок між їх результативністю та фактором раптовості. Так, згідно з результатами проведеного В. П. Бахіним дослідження, 78,4 \% проінтервйованих слідчих вказали на залежність реалізації раптовості від етапів розслідування. За даними аналізу кримінальних справ, проведення обшуків у день порушення кримінальної справи було результативним у 82 \% випадках, а потім результативність цієї слідчої дії різко скорочувалася: упродовж трьох днів - до 25 \%, протягом 10 днів - до $15 \%$ [3, с. 71].

Наведені відомості визначають, що результативність застосування розглядуваного фактору обумовлена, у тому числі, етапом розслідування. Початку розслідування властиві як інформаційна невизначеність слідчого, так і мінімально можливий тиск на його учасників з боку зацікавлених осіб. Особливо, якщо в останніх відсутні відомості про розпочате кримінальне провадження, а проведення слідчих (розшукових) дій характеризуються невідкладністю та швидкістю їх організації. 3'ясування факту розслідування безпосередньо перед проведенням окремих слідчих (розшукових) дій за участі відповідної особи буде неочікуваним для неї. Це, на нашу думку, може суттєво вплинути на хід проведення дії та зайняту учасником позищію. Тож вірогідність отримання достовірних свідчень значною мірою обумовлена фактором раптовості. Правильність його застосування значною мірою залежить від рівня володіння знаннями, підвалини якого закладаються ще в навчальних закладах, у тому числі зі специфічними умовами.

Зокрема, за результатами проведеного М. В. Савельєвою дослідження, 67,7 \% опитаних практичних працівників правоохоронних органів зауважили, що вивченню чинника раптовості було приділено недостатньо уваги в ході їх підготовки у вищому навчальному закладі, а 64,5 \% опитаних вважають за доцільне вивчення чинника раптовості в розділі криміналістичної тактики [4 , с. 5]. Однак, ми вважаємо, що використання фактору раптовості не має обмежуватися лише тактикою проведення окремих слідчих (розшукових) дій. Так визначення, з урахуванням умов, що 
склались, найбілыш доцільного моменту проведення слідчих (розшукових) дій, їх послідовність, учасників, техніко-криміналістичних засобів та інше виходять за рамки криміналістичної тактики та визначаються, як організація діяльності.

Не вдаючись до дискусії про місце фактору раптовості в науці «Криміналістика», вважаємо за необхідне приділити увагу можливості його використання в рамках подолання протидії розслідуванню.

У процесі розслідування раптовість виражається в такій організації слідчої роботи, яка забезпечує непередбаченість змісту й характеру дій слідчого протидіючою стороною [3, с. 145, 149]. Забезпечення наступального характеру не тільки тактичних прийомів, а й розслідування в цілому значною мірою залежить від правильності застосування правоохоронцями фактору раптовості. В умовах протидії розслідування зазначене набуває особливого значення.

Слід погодитися $з$ думкою Р. С. Бєлкіна про те, що для протидіючої сторони несподіваними або раптовими можуть бути:

- сам факт проведення тієї чи іншої слідчої дії або її здійснення в найнесподіваніший час, у непередбаченому місці;

- застосування слідчим під час розслідування будь-якого екстраординарного, нетрадищійного тактичного прийому;

- отримання від слідчого інформації про залучення в доказування осіб, можливість участі яких у даному процесі виключалася протидія стороною або передбачалася на більш пізньому етапі;

- те ж саме й щодо матеріальних об'єктів (слідів злочину і злочинця, інших речових доказів, результатів їх експертних досліджень тощо). Несподіваними тут можуть бути і зміст інформації, що передається про такі об'єкти, і факт їх використання при проведенні слідчої дії [5, с. 4-5].

Таким чином, несподіваними для учасників розслідування та зацікавлених осіб можуть бути використані слідчим такі фактори: обстановки (часу та місця), виду та способу реалізації заходів, прийомів, поінформованості про обставини події тощо.

Прийомами реалізації цих факторів В. С. Кузмичов вважає:

а) проведення слідчої дії, невідомої підозрюваному по вигляду і змісту;

б) роз'яснення цілей, характеру і можливих результатів слідчої дії;

в) використання необізнаності підозрюваного про характер й обсяг інформації, якою володіє слідство;

г) залучення до участі в проведенні слідчих дій спеціалістів та осіб, обізнаних про обставини розслідуваної події;

д) зміна тактики слідчих дій [6, с. 92].

Слідчий, за умов протидії, може змінити не тільки послідовність застосування тактичних прийомів, а й проведення деяких слідчих (розшукових) дій, забезпечуючи тим самим неочікуваний їх характер для зацікавлених осіб.

Відповідно до даних дослідження, при реалізації раптовості працівниками слідчих органів у 7,4 \% випадків намічена мета досягалася завжди, у 76,5 \% - досягалася часто, і в $19 \%$ - не досягалася [7, с. 176].

Зазначене повною мірою може бути визначено й по відношенню до тактичних прийомів, жоден із яких не надає гарантії отримання позитивного результату його 
застосування. Тому раптовість не повинна розглядатися як єдиний варіант дій, а й мають оцінюватися ризики його використання при організації розслідування.

Застосування чинника раптовості в ході провадження вербальних слідчих дій (допит, пред'явлення для впізнання, очна ставка й інших), як правило, наголошує М.В.Савельєва, обумовлено метою спостереження й оцінки впливу на протиборчу розслідуванню особу раптовості. При невербальних (нонвербальних) слідчих діях (слідчий огляд, обшук, призначення і проведення експертизи) найбільше значення матиме сам результат слідчої дії, обумовлений, на думку авторки, раптовістю, а не реакщією протиборчої слідству боку [4, с. 85-86].

Однак висловлена М. В. Савельєвою позиція не позбавлена неточностей. Зокрема, спостереження та оцінка впливу на протиборчу розслідуванню особу, раптовості, виступають критеріями правильності застосування розглядуваного фактора, маркерами у визначенні напрямків проваджуваної дії, а не його метою. Останньою виступають достовірні відомості, отримати які в умовах протидії розслідуванню складно, а іноді не можливо.

Окрім того, потребує врахування не тільки момент, а й суб'єкт застосування розглядуваного чинника. Так вивчення особи, по відношенню до якої застосовуватиметься раптовий характер дій, обумовлює необхідність з' ясування, у першу чергу, соціально-демографічних, психологічних даних особи.

Не бажано, як наголошує О. С. Бабаєв, застосовувати фактор раптовості щодо розумово відсталих обвинувачених. Раптове пред'явлення доказів, несподівана постановка питання викликають у них стан розгубленості, як і в психічно здорових. Але в розумово відсталих цей стан характеризується білышою виразністю, через що вони можуть дати неадекватну реакцію [8, с. 108].

Розрахований на психічне напруження фактор може сприйматися як загроза та призвести до неочікуваних негативних наслідків (агресії, паніки, істерики, хаотичності дій тощо) з боку відповідного учасника.

Захопленою зненацька, на думку 3. Палеського, може бути тільки людина, що володіє здатністю розуміти й міркувати, а також орієнтуватися в навколишній дійсності (той, у кого свідомість порушено, зовсім не відчуває раптовості) [9, с. 108]. Тобто мова не йде про ефективність застосування розглядуваного чинника до зазначеної категорії осіб. У діяльності із вказаними особами є необхідним приділення уваги психологічному їх налаштуванню на проведення слідчих (розшукових) дій.

Найсуворіше дотримання не тільки правових, а й моральних принципів і норм, як наголошує Д. П. Котов, є запорукою об'єктивності й справедливості в діяльності слідчого, а також абсолютно необхідне для забезпечення ефективності розслідування, попередження злочинів, для підтримки високого престижу органів попереднього слідства і всіх правоохоронних органів в цілому [10, с. 43].

Водночас по відношенню до неповнолітніх, і в першу чергу тих, котрі стали свідками та жертвами насильства, піддалися тиску з боку зацікавлених осіб, застосування фактору раптовості обумовлює особливу обережність з боку правоохоронщів.

Заслуговує на увагу й точка зору Л. Л. Каневського, який наголошує, що елемент раптовості при допиті неповнолітнього підозрюваного потрібно використовувати вміло, з урахуванням психічного стану підлітка й тих доказів, якими володіє слідчий. Зокрема, фактор раптовості можна використовувати шляхом пред'явлення 
неповнолітньому переконливого доказу, що свідчить про обізнаність слідчого в деталях розслідуваної події [11, с. 54].

Застосування тактичних прийомів, що грунтуються на раптовості, можуть призвести до негативних наслідків у вигляді навіювання, «закриття» неповнолітнього та неможливості продовження подалышого спілкування з ним. Тобто, по відношенню до зазначеної категорії, застосування фактору раптовості повинно мати умовний характер.

Однак, оцінка особи лише за віком, на нашу думку, може бути не об'єктивною. Так злочинність неповнолітніх останнім часом набуває істотних змін, зокрема «кваліфікованості» дій, ознак так званої «дорослої», що не може не впливати на діяльність правоохоронщів.

За наявності стійкої позищії протидії розслідуванню (давання неправдивих свідчень, відмова від раніше даних показань, висування алібі, здійснення тиску на учасників провадження тощо), відсутність налаштування на комунікащію зі слідством, недієвість попередньо використаних прийомів та заходів переконання в недоцільності зайнятої позищії обумовлюють необхідність застосування правоохоронцями заходів, що грунтуються на раптовості. Через те відмовлятися від застосування розглядуваного фактору лише на підставі такого критерію, як вік особи, на нашу думку, є помилковим. Однак, у кожному конкретному випадку має забезпечуватися індивідуальний підхід, з безумовним дотриманням принципів (законності, етичності та інших).

Не меншого значення в реалізації неочікуваного характеру дій має й обстановка. Так неправильне обрання часу, місця, способу реалізації намірів унеможливить отримання очікуваних слідчим результатів. Відповідно, «раптове» проведення тих чи інших слідчих дій, як наголошує І. С. Биховський, перетворюється на нікчемний і непотрібний задум [12, с. 58].

Наведене значною мірою залежить від професійного рівня слідчого, неочікуваного для відповідних осіб, застосування наявних в його розпорядженні засобів та заходів. Критерієм правильності використання розглядуваного фактору буде кількість та змістовна характеристика отриманої інформації.

Закономірним підтвердженням обгрунтованості розгляду впливу раптовості служать наступні дані: 75,3 \% практичних працівників вважають, що використання чинника раптовості залежить від професійної майстерності працівників слідства [7, с. 177].

Від рівня майстерності слідчого залежить не тільки результативність розглядуваного фактору, а й проведення слідчих (розшукових) дій та розслідування в цілому.

Варто наголосити на тому, що й протидіюча сторона по відношенню до слідчого може приймати заходи з використанням фактору раптовості шляхом:

- повідомлення тих обставин, які слідчий на даний момент не мав або сприймав їх по іншому, котрі можуть стати підгрунтям для неочікуваних умовиводів, та формування на їх підставі нових версій, визначення напрямків розслідування;

- зміни свідчень, відмова від їх давання, підтримання раніше даних відповідним учасником або, навпаки, щиросердне зізнання;

- висування вимог залучення захисника;

- подачі клопотань, скарг, відводів слідчому;

- симулящії погіршення стану здоров'я (фізичного, психічного); 
- звинувачення слідчого в упередженому ставленні тощо.

Однак зазначений перелік не є вичерпним. Можуть бути виявлені й інші, здійснювані зацікавленими особами прояви протидії розслідуванню. Тож фактор раптовості має можливості двостороннього характеру застосування, як правоохоронцями по відношенню до учасників розслідування, так і у зворотному порядку. Це значною мірою впливатиме на можливість зміни кількості інформації в сторін розслідування. Ефективність впливу однієї сторони на іншу визначається їі фаховими якостями, умінням застосування розглядуваного фактору.

Усвідомлення та прогнозування слідчим можливості застосування по відношенню до нього відповідних проявів, мінімізуватиме очікуваний зацікавленими особами характер впливу.

Висновки. В очікуваний позитивний результат застосування фактору раптовості має бути закладене й припущення про негативні його наслідки, зокрема передчасне викриття перед зацікавленими особами наявної в слідчого інформаційної бази.

Критеріями правильності використання розглядуваного фактору виступає спостереження та оцінка впливу на протиборчу розслідуванню особу. Це сприятиме визначенню ходу проведення в отриманні відомостей про обставини події, що в умовах протидії розслідуванню набуває особливого значення.

Застосуванню розглядуваного чинника до осіб з психічними розладами має характер недоцільності, а по відношенню до неповнолітніх несе умовний смисл. Варто враховувати факт того, що фактор раптовості має можливості двостороннього характеру застосування, як правоохоронщями по відношенню до учасників розслідування, так і у зворотному порядку. Готовність слідчого до цього зменшить можливості отримання зацікавленими особами позитивного результату від його застосування.

Тож подальші наші дослідження зосереджуватимуться в напрямку застосування фактору раптовості при проведенні окремих слідчих (розшукових) дій в умовах протидії розслідуванню.

\section{Використані джерела:}

1. Игнатьев М. Е. Фактор внезапности, его процессуальное и криминалистическое значение для расследованияпреступлений. / М. Е. Игнатьев. М.: Юрлитинформ, 2004. $144 \mathrm{c}$.

2. Криминалистическое обеспечение деятельности криминальной милиции и органов предварительного расследования / Под ред. Т. В. Аверьяновой и Р. С. Белкина. М.: Новый Юрист, 1997. 400 с.

3. Бахин В. П. Криминалистика. Проблемы и мнения (1962-2002). / В. П. Бахин. К. 2002. 268 c.

4. Савельєва М. В. Теоретические и практические основы использования фактора внезапности в уголовном судопроизводстве: автореф. дис...канд. юрид. наук: спец 12.00.09 «Уголовный процесс, криминалистика и судебная экспертиза; оперативно-розыскная деятельность» / М. В. Савельєва. Саратов, 2003. 24 с.

5. Белкин Р. С. Фактор внезапности, его учет и использование при расследовании преступлений: Лекция. М.: Академия МВД России, 1995. С. 4-5.

6. Кузьмичев В. С. Научные основы и практика реализации принщипа внезапности в следственной деятельности дис. ...канд. юрид. наук: 12.00 .09 / Кузьмичев Владимир Сергеевич. Киев, 1986. 
7. Бахин В. П., Карпов Н. С. Некоторые аспекты изучения практики борьбы спреступностью (данные исследований за 1980 - 2000 гг.) / В. П. Бахин, Н. С. Карпов. К.: Национальная академия внутренних дел Украины, 2002. 458 с

8. Бабаев О. С. Концептуальные основы и тенденции развития современной тактики: дис. ... канд. юрид. наук : 12.00.09./ Бабаев Октай Сабирович. Москва 1998. 195 с..

9. Палеский 3. Психологические аспекты внезапности / / Военная мысль. 1971. № 7. С. 84.

10. Котов Д. П. Вопросы судебной этики. / Д. П. Котов. М..: Знание, 1976. 64 с.

11. Каневский Л. Л. Организация расследования и тактика следственных действий по делам несовершеннолетних. / Л. Л. Каневский. Уфа : Башкир. гос. ун-т,1978. 86 с..

12. Быховский И. Е. Процессуальные и тактические вопросы проведения следственных действий Учебное пособие / Быховский И. Е. Волгоград: НИиРИО ВСШ МВД СССР, 1977.95 c.

\section{References:}

1. Ignatev, M. E. (2004) Faktor vnezapnosti, ego processualnoe i kriminalisticheskoe znachenie dlya rassledovaniya prestuplenij. M. E. Ignatev (Ed.). Moskva, Yurlitinform. [in Russian].

2. Kriminalisticheskoe obespechenie deyatelnosti kriminalnoj milicii i organov predvaritelnogo rassledovaniya. (1997) T. V. Averyanova, \& R. S. Belkin (Eds.). Moskva, Novyj Yurist. [in Russian].

3. Bahin, V. P. (2002) Kriminalistika. Problemy i mneniya (1962-2002). V. P. Bahin (Ed.). Kyiv. [in Russian].

4. Savelyeva, M. V. (2003) Teoreticheskie i prakticheskie osnovy ispolzovaniya faktora vnezapnosti v ugolovnom sudoproizvodstve. Extended abstract of candidate's thesis. «Ugolovnyj process, kriminalistika i sudebnaya ekspertiza; operativno-rozysknaya deyatelnost» M. V. Savelyeva (Ed.). Saratov. [in Russian].

5. Belkin, R. S. (1995) Faktor vnezapnosti, ego uchet i ispolzovanie pri rassledovanii prestuplenij: Lekciya. Moskva, Akademiya MVD Rossii, 4-5. [in Russian].

6. Kuzmichev, V.S. (1986) Nauchnye osnovy i praktika realizacii principa vnezapnosti v sledstvennoj deyatelnosti. Candidate's thesis. Kuzmichev Vladimir Sergeevich (Ed.). Kyiv. [in Russian].

7. Bahin, V. P., Karpov, N. S. (2002) Nekotorye aspekty izucheniya praktiki borby s prestupnostyu (dannye issledovanij za 1980 - 2000 gg.). V. P. Bahin, N. S. Karpov (Eds.). Nacionalnaya akademiya vnutrennih del Ukrainy. Kyiv, 176. [in Russian].

8. Babaev, O. S. (1998) Konceptualnye osnovy i tendencii razvitiya sovremennoj taktiki. Candidate's thesis. Babaev Oktaj Sabirovich (Ed.). Moskva, 108. [in Russian].

9. Paleskij, 3. (1997) Psihologicheskie aspekty vnezapnosti. Voennaya mysl-Military thought, 7, 84. [in Russian].

10. Kotov, D. P. (1976) Voprosy sudebnoj etiki. D. P. Kotov (Ed.). Moskva: Znanie, 43. [in Russian].

11. Kanevskij, L. L. (1978) Organizaciya rassledovaniya i taktika sledstvennyh dejstvij po delam nesovershennoletnih. L. L. Kanevskij (Ed.). Ufa: Bashkir. gos. un-t, 54. [in Russian].

12. Byhovskij, I. E. (1997) Processualnye i takticheskie voprosy provedeniya sledstvennyh dejstvij. I. E. Byhovskij (Ed.).Volgograd: NIiRIO VSSh MVD SSSR, 58. [in Russian]. 


\section{Плетенец В. Н.,}

кандидат юридических наук, доцент, доцент кафедры криминалистики, судебной медищины и психиатрии Днепропетровского государственного университета внутренних дел (г. Днепр, Украина)

\section{ВОЗМОЖНОСТИ ИСПОЛЬЗОВАНИЯ ФАКТОРА ВНЕЗАПОНОСТИ В УСЛОВИЯХ ПРОТИВОДЕЙСТВИЯ РАССЛЕДОВАНИЮ}

В статье рассматриваются возможности использования фактора внезапности в преодолении проявлений противодействия расследованию. Отмечается, что конфликт интересов обусловливает формированием противостояния между указанными сторонами, который усложняет процесс расследования. Установление же обстоятельств происшествия становится возможным путем неожиданного для соответствующих участников принятия мер со стороны сотрудников правоохранительных органов. Отстаивается позиция,что наблюдение и оценка воздействия на противоборствующее расследованию лицо являются критериями правильности применения фактора внезапности. Целью его использования выступают достоверные сведения об обстоятельствах расследуемого события. Подчеркивается необходимость учета не только момента, но и характеристик субъекта применения рассматриваемого фактора.

Ключевые слова: фактор внезапности, следственные (розыскные) действия, информация об обстоятельствах происшествия, проявления противодействия расследованию.

\section{PletenetsV., Candidate of Law, Associate Professor, Associate professor of the Department of criminalistics, forensic medicine and psychiatry of Dnepropetrovsk State University of Internal Affairs (Dnipro, Ukraine)}

\section{THE POSSIBILITY OF RESORTING TO SURPRISE IN THE CONTEXT OF COUNTERING AN INVESTIGATION}

The article discusses the use of the element of surprise in overcoming resistance to investigation. It is noted that a conflict of interest leads to a confrontation between the parties, which complicates the investigation process. However, it is possible to establish the circumstances of an incident by taking action on the part of law enforcement officials that is unexpected to the parties concerned.

The position, observation and evaluation of the impact on the person opposing the investigation are the criteria for the correct application of the element of surprise. Its purpose is to provide reliable information on the circumstances of the incident under investigation.

The circumstances in which the investigation is resisted add to the need to overcome its manifestations. Emphasis is placed on the need to take into account not only the moment but also the characteristics of the person to which the factor in question applies. Thus, an examination of the person 
to whom the act of surprise would be applied. The psychological characteristics of the individual must be ascertained, first and foremost, through socio-demographic data.

The use of the element of surprise as well as the tactics based on it in relation to mentally ill and underage persons can lead to negative consequences in the form of: aggression, panic, hysteria, chaotic actions, suggestion, "closure" and no further communication with them.

Suddenness. It is noted that the level of skill of the investigator depends not only on the efficiency of the factor in question, but also on the conduct of investigative (search) actions and investigations in general. Emphasis is placed on the fact that the adversary may also use the element of surprise against the investigator. The element of surprise thus has the potential of being applied bilaterally by law enforcement officials to the parties to the investigation and vice versa.

The investigator's prediction of the possibility of the relevant manifestations against him or her will not have the nature of the impact expected by the persons concerned.

Keywords: Element of surprise, investigative (investigative) actions, information on the circumstances of the incident, resistance to the investigation.

DOI: 10.33766/2524-0323.90.247-263

УДК 343.983.22

О. С. Соколов,

завідувач відділу досліджень зброї лабораторії досліджень, сертифікації зброї та обліку

Державного науково-дослідного експертно-криміналістичного центру Міністерства внутрішніх справ України (м. Київ, Україна) e-mail:ballistekc@gmail.com

iDhttps://orcid.org/0000-0001-7613-1590

\section{ОСОБЛИВОСТІ ВСТАНОВЛЕННЯ ГРУПОВОЇ НАЛЕЖНОСТІ ВІДНОВЛЕНОЇ НЕЙТРАЛІЗОВАНОЇ (ДЕАКТИВОВАНОЇ) ВОГНЕПАЛЬНОЇ ЗБРӦ̈ ЗА СЛІДАМИ НА ВІДСТРІЛЯНИХ КУЛЯХ ТА ГІЛЬЗАХ}

Стаття присвячена особливостям слідоутворення на кулях та гільзах, відстріляних із відновленої нейтралізованої вогнепальної зброї (макетів зброї масо-габаритних, учбової, учбово-розрізної та музейної зброї). Досліджено конструктивні ознаки слідоутворюючих поверхонь нейтралізованих частин зброї та сліди, які утворюються при їх відновленні. Сформовано комплекс ознак у слідах зброї на відстріляних кулях та гільзах, які вказують на застосування відновленої нейтралізованої вогнепальної зброї. Розглянуті можливості сучасного мікроскопічного обладнання при вирішенні ідентифікаційних завдань та завдань щодо встановлення групової належності зброї за слідами на відстріляних кулях та гільзах.

Ключові слова: відновлена зброя, експертиза зброї, криміналістичне дослідження, нейтралізована зброя, деактивована зброя, ознаки відновлення зброї, сліди на відстріляних кулях і гіљзах, макети зброї масо-габаритні, порівняльний мікроскоп «Leica FSC», багатофункціональний комплекс ідентифікації куль та гільз «BalScan».

Постановка проблеми. Результати аналізу слідчої та судової практики дозволяють виявити тенденщію до збільшення частки вогнепальної зброї, котра виготов-

(C) Соколов О. С., 2020 